\title{
The quest for context-relevant online education
}

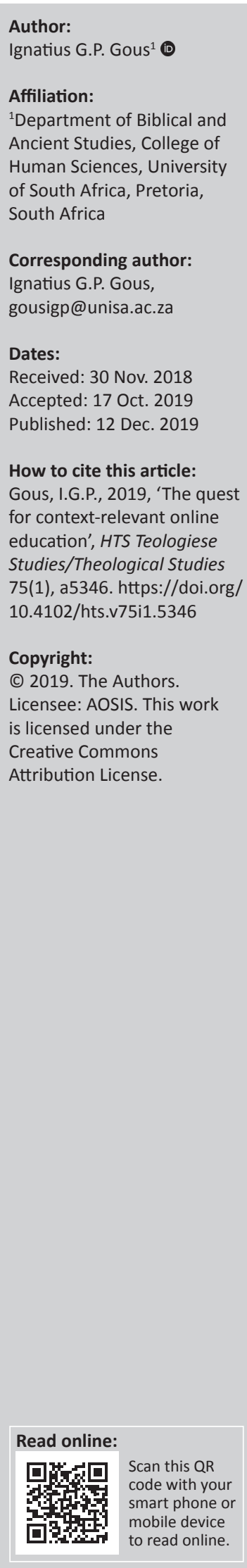

Is it possible to provide context-relevant education to a diverse and dispersed body of students via online presented courses? Contextual relevance is called for by students and the public alike, as can also be seen in the \#fallist movements. More traditional academics and institutions argue for retaining excellence from the past and known knowledge still to be taught. In this conceptual article, education is seen as a mastery of knowledge expanses by integrating Data and Information into Knowledge and Wisdom (D-I-K-W). Departing from the learning sciences, especially mind, brain and education science and its application in culturally appropriate learning, it is argued that including effective learning strategies in online courses, especially application-oriented strategies, can help students to apply knowledge from the past to contexts in the present, thereby attaining context-relevant education. However, the application of learnt material to situations brings forward another dimension, namely, the future, which is Volatile, Uncertain, Complex and Ambiguous (VUCA). In applying and making decisions, it is helpful to attend to the Cynefin framework, attending to the domains of the obvious, the complicated, the complex, the chaotic and the disorder. Excellence from the past and relevance in the present should, therefore, be augmented by abilities aimed at future readiness. Context-relevant online education should therefore attend to the past, the present and the future.

Keywords: Scholarship of teaching and learning; Mind, brain, and education science; Cultural appropriate learning; Meaningful learning; Decolonisation of the curriculum; \#fallist movement; D-I-K-W; VUCA; Cynefin.

\section{Online education - Entertaining the past, the present and the future}

Is it possible to provide context-relevant education to a diverse body of students via online presented courses?

Traditionally informal (and later formal) education and training was provided orally and by means of human interaction. Parents and clan members shared relevant competencies with novices, as did sages and teachers with their learners and students. The technological advancement of writing by hand and the later invention of printing enabled teachers to be spatially and synchronically removed from those learning from them, but the gold standard of education was still human interaction where someone taught the hand-written or printed transmitted materials face-to-face and synchronically. Even so, a small separate stream called Distance Education developed, where transactional distance was the order of the day and initially printed material was taught and learnt mostly without direct human interaction (Taylor 2001:3).

A further technological advancement, namely, computers and the Internet, enabled multisensory teaching and learning at a distance, which involved more than merely reading. The availability thereof, and sometimes additional stimuli as we will see when attending to the \#rhodesmustfall and \#feesmustfall phenomena, made presenting courses and education online a growing reality, with more and more institutions of learning in all parts of the world adopting it as a mode of tuition.

One characteristic of online education is that it provides education to students wherever they might find themselves. That is the core strength thereof, in the sense that it provides access to millions of students unwilling or unable to attend face-to-face teaching and learning institutions. One of the biggest challenges of online education, however, is to make learning contextually relevant and meaningful to students in vastly different physical and cultural contexts and to provide 'culturally appropriate education' (Brown-Jeffy \& Cooper 2011:65-84; Reyhner, Gilbert \& Lockard 2010; Zhou \& Fischer 2013:225). Hence, the question: is an online course able

Note: OEH: The Online Educated Human: Teaching values, ethics, morals, faith and religion at a distance, sub-edited Ignatius Gous (University of South Africa). 
to educate a specific human in a particular context with relevant, useable, applicable and meaningful knowledge? Can online education provide a globally dispersed body of students through education, defined here as developing 'wisdom' in the sense of the data-information-knowledgewisdom flow of sense-making (the D-I-K-W pyramid or flow diagram - see Henry 1974; Rowley 2007:164; Wallace 2007:13), or, as Zeleny (2005:14) describes, the taxonomy of knowledge in terms of know-nothing (data)-knowwhat (information)-know-how (knowledge)-know-why (wisdom)-know-for-sure (enlightenment)?

In this conceptual article, the quest to provide meaningful education via online courses will be debated from the vantage point of the scholarship of teaching and learning, more specifically the cognitive sciences in the mind, brain and education sciences variety (Caine \& Caine 2006:53-61; Carew \& Magsamen 2010:685-688; Cozolino \& Sprokay 2006:11-19). Learning is the backbone of education, and therefore it is necessary to know what learning entails and how it is performed. Deliberating online education is done from the vantage point of the learning sciences, as the vehicle of education and the practical way in which wisdom as a comprehensive sense-making endeavour can be attained. The concept of what effective learning entails, and how this can be done online, is presented.

The concept of 'relevance' will be discussed, initially attending to two aspects, namely, the particular and the universal. The first (the particular) is a contextual quest for meaning pronounced in student movements who called for education to be more relevant to their contexts - the so-called \#fallist movements in South Africa and further afield. Apart from being a practical instance of the need for relevance, it had the unexpected consequence that the disruptions it caused on contact university campuses forced the tuition to switch to an online mode, where lecturers who had no or limited experience in online tuition had to present their lectures from behind glass and screen as it were.

The second aspect in discussing relevance is to consider the universal, in other words, whether it is necessary and possible to include universal aspects in online education and still meet the need for contextual relevance of a spatially and culturally diverse student body. Do we share common questions relevant to all of humanity that we need to address in order to be properly educated? If so, can we provide examples thereof, and is it possible to address it in online courses?

The conclusion reached after these deliberations is that relevance is attained by focusing on both the universal and the particular, and neither should be neglected in any online course. In terms of universities and their histories, Mamdani (2019:12) refers to this as 'the gown and the town', the global scholar focussing on excellence and the public intellectual focussing on relevance. According to him, universities need both relevance and excellence. Focussing on only one aspect will either perpetuate or repeat a previous wrong. How this can be made a reality in online courses, which has the danger of being decontextualised, is to make use of learning strategies that support contextualisation, such as being practice-orientated and utilising open-ended assignments and assessments.

This way of learning, however, brings a third aspect into play, which is necessary to consider. If application of learnt material is important, then it is necessary to know where to apply it. A characteristic of all contexts is rapid change. Therefore, it is important to consider what relevance means in rapidly changing contexts. How do we, stooped in one context, teach students from different contexts to make the content what is being taught to them relevant in a plethora of disruptively changing contexts? In this situation, merely teaching content is not enough. The only way to manage change is to add a focus on the abilities enabling life-long learning and adaptation.

The conclusion is that relevant learning for a learner who is being educated online is to attend to three aspects, namely, past, present and future, and only then we can approach contextual relevance. Only by doing this one might be properly educated. Only by keeping all of this in mind can we master data and information, and approach knowledge and wisdom.

Therefore, we need first to consider what learning is.

\section{Effective learning - Life-long and life-wide learning strategies}

It is needless to say that learning is the basis of education. It is also true that often it is taken for granted. Lecturers sometimes expect that students should have been taught at school about how to learn, or that the fact that they are at the university level, they already know how to learn, and that learning itself, therefore, need not be addressed in courses online or face-to-face.

However, research has shown that worldwide many students are not well prepared for tertiary studies, even though they might have completed their school subjects successfully (Brown, Roediger \& McDaniel 2014:ix, 3, 10; Doyle \& Zakrajsek 2013:xi, 2, 12-13). Schools focus more on coaching learners to pass than on teaching them how to learn. Added to this is the fact that many South African schools are being classified as dysfunctional or under-performing (Pretorius 2014:51). It is expected from university students that they need to study independently and master volumes of work on their own. One of the reasons for the higher than expected dropout figures and non-completion rates is related to the inability of students to study effectively. Therefore, an important part of the solution for this state of affairs is that students need to learn how to learn effectively - even those students who are performing adequately or well but who still use obsolete and ineffectual study strategies. 
Added to the reality that students do not always know how to study effectively is the fact that many lecturers are not adequately trained on how to teach and model learning (Biggs \& Tang 2011: 3; Entwistle \& Ramsden 2015; Laurillard 2002). Lecturers are employed for their disciplinary competency and subject knowledge and rarely evaluated based on their pedagogical skills and tuitionary knowledge. This is a concern in face-to-face classes, but it may be mitigated in a class situation because students might clarify uncertainties by asking questions. However, when these classes are presented online, the chances of misapprehension become more of a possibility.

It is therefore important that students need to know how to learn effectively, whilst at the same time lecturers need to know how to impart to their students the ability to learn effectively. This, however, does not happen, with dreadful costs to student success, and even more pronounced consequences for online students.

To address this state of affairs, online educators should become knowledgeable about effective learning and able to support learning.

\section{Effective learning: Needs and strategies for lecturers and students}

Mind, Brain And Education Science (MBES), as it is known in the United States, or Neuro-Education as it is called in the UK, is involved in reputable research about what effective learning is. Articles and books such as Brown et al. (2014), Dunlosky et al. (2013) and Doyle and Zakrajsek (2013), as well as journals such as Mind, Brain, and Education ${ }^{1}$ and the Journal of the Learning Sciences, ${ }^{2}$ are contributing to neuro- and cognitive science research as well.

This body of ongoing research has indicated that students, and often their lecturers as well, still use ineffective learning strategies, such as cramming a day or two before a test or exam, and using strategies such as reading and re-reading, highlighting and underlining, and making or buying summaries.

In spite of using ineffective study strategies, many students still pass and even pass well. However, there are better ways available, such as practice testing, varied repetition and applying what is being learnt to real-life situations - the latter being used extensively in fields like medical education and other vocational training sessions, but not easily replicated in online courses. For this reason, to my knowledge, there is no online-only medical school in the world.

The results of research on effective learning are not impacting many lecturers and students, with detrimental effects on teaching and learning.

1.See https://onlinelibrary.wiley.com/journal/1751228x.

2.See https://www.isls.org/communities/journal-of-the-learning-sciences.

\section{Culturally appropriate learning}

With the world becoming a global village, or more precisely, a globe of villages, multitudes of worldviews and viewpoints in one class are becoming the norm. This is even more so in online classes, with students enrolled from all over the world. Education needs to take this into account - but the question is why and how, and especially based upon which theoretical point of departure.

Respect for the viewpoints and worldviews of others is a topic that is receiving ample attention (Baumgartner \& Johnson-Bailey 2008:45-53). Translating this into pedagogy, teaching and learning, Ladson-Billings (1995) called it 'culturally relevant pedagogy' and describes it as:

$[A]$ pedagogy of oppression not unlike critical pedagogy but specifically committed to collective, not merely individual, empowerment. Culturally relevant pedagogy rests on three criteria or propositions: (a) students must experience academic success; (b) students must develop and/or maintain cultural competence; and (c) students must develop a critical consciousness through which they challenge the current status quo of the social order. (p. 160)

Other terms for the same pedagogical goal of being academically successful, as well as culturally relevant, are 'culturally congruent' (Mohatt \& Erickson 1981:105), 'culturally appropriate' (Au \& Jordan 1981:139), 'culturally compatible' (Jordan 1985:105; Vogt, Jordan \& Tharp 1987:276) and 'culturally responsive' (Au 2009:179; Cazden \& Leggett 1981:69; Erickson \& Mohatt 1982:132; Lee 1998:268).

Zhou and Fischer (2013:225-226) addressed this from a mind, brain and education science point of departure. According to them, there is a complex and dynamic relationship between gene, brain and culture. We are all born with similar brain structures that constrain how we make sense of our worlds. Cultural learning and experiences, however, shape the anatomy and function of the brain, which ultimately influences human behaviour. These processes underlie the phenomenon of neuroplasticity, and education is the way that changes our brains and behaviour. 'Successful educational reform and pedagogy require that teachers become culturally and neuroscientifically literate', say Zhou and Fischer (2013:225-231). The implication of this is that the histories and experiences of minorities or marginalised communities should be included in curricula and courses.

Seen in this way provides a practice-tested and theoretically sound way to understand and celebrate differences in educational settings. It affords a starting point with an inclusive end goal in mind. We need cultural intelligence in the multicultural worlds we live in, and the cultural intelligence we need is the capacity of individuals to function effectively in multicultural situations (Earley \& Ang 2003:12, $20,99,138,186,296)$.

The question that arises is, 'how can this be done in responsible and workable ways in which not only valid established wisdom is respected but also novel and local wisdom is embraced? 


\section{The present and the need for relevant learning: The example of the \#fallist movements, with a decolonised agenda}

The need for meaningful teaching and learning is vividly foregrounded by the decolonisation debate. The \#fallist movement in South Africa became visible with the \#rhodesmustfall crusade, when students protested against the statue of Cecil John Rhodes at the entrance of the University of Cape Town campus. ${ }^{3}$ Some of the students felt that Rhodes was a racist and that he exploited the local population, and therefore his legacy should be erased from the campus. This movement subsequently resonated in protests at Oxford University in the UK (Chaudhuri 2016).

This then evolved into a \#feesmustfall movement, where students added complaints about high university tuition fees, which, according to them, excluded many previously disadvantaged students from educational opportunities ${ }^{4}$ (for a discussion about it, see Archer 2018).

The decolonisation debate voiced similar concerns about the dominance of the Western academic tradition and the exclusion of contributions from Africa and other non-Western origins (Ndlovu-Gatsheni 2013:46-51). These lead to feelings of estrangement, non-belonging and purposelessness. At some universities, the \#afrikaansmustfall movement also linked to the previously mentioned movements because some South African students deem Afrikaans as the language of the oppressor even though they prefer to be taught in the colonial language English $^{5,6}$ (Dube 2017:13-27).

How this will unfold and where all of this will lead to are still to be seen. It stimulated debate about it in conferences and articles, academic and popular media. It also leads to violence and damage of property, such as the burning of auditoria, laboratories, libraries and other facilities. It even resulted in the disruption and subsequent suspension of classes and academic programmes, preventing many students to attend classes, write examinations and eventually preventing them to complete their academic years.

The decolonisation debate is complex and portrays varied perspectives. Some authors come from an educational perspective, such as Heleta (2016), who is of the opinion that South Africa must dismantle the hegemony of Eurocentrism and completely rethink, reframe and reconstruct the curriculum to reflect an African perspective. Some come from an economic perspective, about the effectiveness of curriculum implementation and change (Musitha \& Mafukata 2018). Costandius et al. (2018) provide insights and

3.See https://www.sahistory.org.za/dated-event/chumani-maxwele-ignites rhodesmustfall-movement-uct.

4.See https://ewn.co.za/Topic/Fees-must-fall.

5.See https://www.iol.co.za/news/south-africa/gauteng/why-were-bringingafrikaansmustfall-back-2026394.

6.See https://mg.co.za/article/2016-03-10-whiteness-not-afrikaans-must-fall. resources for lecturers to assist them in decolonising their spaces of teaching and learning. According to Lebeloane (2017), equity and social justice is also an interest, and school curricula should be transformed to pursue this. Le Grange (2018) focusses on the phenomenon of decolonisation as such in order to open up ways of (re)thinking the university curriculum. Sayed, Motala and Hoffman (2018) provided a meta-analysis of teacher education at four different South African universities, with the goal of influencing teacher education. Fomunyam (2017) followed a pedagogical approach, arguing that curriculums are shaped by power dynamics and that a plurality of voices is vital for the effectiveness of the decolonisation process and the enhancement of curriculum responsiveness.

The debate is rich in perspectives, which is promising to be transformative. However, it also seems the debate is at an either-or position. There is an existing dominant position and tradition reflected in course contents, which students either accept or reject. Then there is an opposing and alternative position challenging the dominant tradition, hoping to unseat and displace it.

Faced with these binary and opposing views, the questions are as follows: 'how should humans be educated, whether face-to-face or in online mode?', 'Is it a matter of choosing the old and rejecting the new, or vice versa?' and 'Are there several, even competing and opposing versions of the wisdom-continuum that should be taught?' To support the debate, a perspective focussing on the foundation of the human learning endeavour is offered. Learning in any context and all contexts should reflect on the metaquestion of learning as such.

An essential characteristic of this decolonisation agenda relates to the experience of alienation (Nyamnjoh 2017: 256-260). The students struggle to master the prescribed content, which may be because of many reasons; however, one reason is that because it does not speak to their lived reality, they are not motivated to learn. They therefore feel that if the curriculum changes, they will perform better in their studies.

The aim of education is to teach data, information and knowledge that is 'state of the art', but at the same time to point out differences about what 'state of the art' might mean in different contexts and for different people. It should aim to occupy and transverse the area between positions, occupying different positions that are relevant at a specific moment in time.

What is 'state of the art'? What is relevant course content? What will be experienced and seen as having attained wisdom?

If students in face-to-face situations experience the curriculum as not relevant to their local context, how much more are the chances for online students from potentially thousands of different contexts to feel the same? How do we obtain relevance in this situation? 
One way to define relevant teaching is to start from the present situation, the current condition, namely, local presentday pressing issues and needs, the flavour of the moment in a particular context. This is valid because the here-and-now is an important aspect of relevance. Another way is to start with the human condition, namely, to seek what is shared amongst humans of all times and in all contexts. This is also important because we are one human race with shared characteristics, which forms the context of all we are and do. If we choose one of these ways over the other, the result may be that either we have to throw away what has been around us for a long time, or we have to ignore what is emerging in the now. It could therefore be constructive and productive to explore the joining ground between the universal and the particular.

When confronted with pressing needs and issues, it makes sense to 'think fast', as Kahneman (2011:368-371) pointed out. It may save lives to do so. However, it is equally important to 'think slow' and to understand what the bigger picture is. In this sense, I will first conceptualise by starting with descriptions of the shared and universal human condition, then move to research conducted about culturally relevant teaching and, finally, talk about the practical implementation of this in real-life courses and classes.

Therefore, we also need to consider 'the past', and what most (or even all) might share.

\section{The past and meta-questions about the human condition}

Proponents of the \#fallist movements make the accusation that courses are generally too 'Western' in terms of orientation and content, ignoring and shunning local knowledge. For this reason, they want it to be discarded and substituted with local and what is in their view a more relevant orientation and content. This may be a valid critique, and it is especially a real danger that online courses might be so context specific to the context of origin that it loses relevance in the contexts where the students find themselves in.

However, local context always fits into broader contexts of varying levels of generalisation, from specific disciplinary contexts to more general contexts of being human. If 'Western' is not acceptable with too tainted a history, are there any other mega- or meta-contexts which can contribute to a more general contextual relevance?

The cognitive sciences depart from the premise that all humans have brains with similar architecture and minds with comparable ways of thinking, and only over time does a unique way of being and thinking develop based on contextualised experience. In order to try to fathom some shared contextually relevant issues, I attend to the so-called life questions.

How do we know what the questions are that life is posing to us? In contemplating this question, I start with meta-questions posed by the oldest inhabitants of Southern Africa, namely, the San Bushmen. Then I refer to very old creation myths, centring on basic human experiences of order and chaos. Continuing in a religious vein, meta-questions emanating from experiences behind biblical stories are discussed, followed by widening the scope again to understand the shared and the particular of religion as such. The goal of all of this is to highlight the continuous interplay between the universal and the particular, the shared and the idiosyncratic.

Everyday experience offers itself as the obvious enquirer, with the daily issues we have to contend with taking precedence. It is therefore natural to devote all our attention to trying to come up with answers to the here-and-now questions. It is important to do this because often those questions are life-and-death issues, threatening of existence and making it difficult to find meaning in life.

It is, however, also true that those immediate questions are arising from more fundamental questions and issues, which should also be heard and understood. Having a limited perspective on the embeddedness of questions in a larger horizon of meta-questions may lead to misunderstanding the true origin of our everyday questions, and consequently misunderstanding what answers may be addressing them.

How do we pose meta-questions? What is ultimately questioning meaning in life? How and where do we look for answers to these meta-questions?

In terms of learning, what is meaningful learning? According to the decolonisation debate, meaninglessness arises from oppression and alienation, and the answer is to get rid of what is Western in the curriculum. Is that a valid question and answer?

Questions about the meaning of life have been posed since time immemorial, preceding current civilisations. Life is difficult, Scott Peck (1978:13) remarked, and that has been the case since people have come into existence. Answers about this have been suggested ever since too, about both specifics, as well as reflecting on meaning in life as such. This has especially been carried out in religions, which were the custodians of stories and reflection about the human condition.

The San Bushman were some of the oldest inhabitants of the southern part of Africa. They did not leave any writings, but their wisdom was transmitted orally. Sir Laurens van der Post, who lived amongst them, wrote (Dyer 2009):

The Bushmen in the Kalahari Desert talk about the two 'hungers'. There is the Great Hunger and there is the Little Hunger. The Little Hunger wants food for the belly; but the Great Hunger, the greatest hunger of all, is the hunger for meaning. (xiii)

Learning is the way through which we acquire skills, knowledge and understandings necessary to satisfy and 
meet both hungers. Learning that focusses on only one of the two is not effective.

Ancient religions documented in word and imagery the important issues to the people of their times. Peterson (1999:19-32, 89-136) gives a description of the meta-questions posed in ancient cultures and religions that were the basis of some of the current major religions.

According to these ancient mythical stories, we think about our human condition as a forum for action, where we journey between the known and the unknown. Humans have two basic needs, namely, the need for order and predictability in their lives, coupled with an equal need for growth and renewal. Order, however, may have the tendency to degenerate into rigidity, whilst growth may degenerate into chaos. The human condition is to be carved out between these opposites by a mediator. These life truths are communicated in creation myths, namely, life truths in story format, making use of three meta-archetypes, namely, as a father figure, a mother figure and a child or hero figure. The father symbolises order, the known, explored territory - in Jungian terms our collective consciousness. The mother symbolises chaos, the unknown, unexplored territory and as such our collective unconsciousness. The child symbolises the mediating consciousness, being on a hero's journey, departing from a position of order, through a situation of chaos, towards a wiser order. He has to overcome the tyranny of the father's order to change it, and also challenge the chaos of the mother to obtain a new life from it. In doing this, the child becomes the Wise King/ Queen type.

In Egyptian mythology, it is about Isis, her husband Osiris who was murdered by his brother Seth, and their son Horus. In Babylonian mythology, the mother figure is Tiamat, Apsu is the father (slain by Ea), and the son is Marduk. This is also the story to which Genesis 1 reacts after the fall of Jerusalem in 586 BCE (Gous 2007). Their known order of land, king and city is destroyed, chaos is threatening, and a new sabbatical order is constituted. In Christian faith, it is about the Father, the Holy Spirit and the Son (Peterson 1999:386)

The implication of these basic human needs is that every culture and dispensation will not only pursue some kind of fixated order but also needs growth and renewal to create a new order. The interplay between order and renewal is what matters. Contextual relevant and meaningful learning entails the mastery and true understanding of ageless and young systems of order, accepting some aspects of order but also critiquing and breaking down of other aspects thereof. Renewed growth should also be understood and pursued in such a way that it does not lead to unbridled chaos. This is the realm of the son, and attaining this balance is to reach integrative competency in the sense of true wisdom, combining the aspects of data-information-knowledgewisdom.
In the Christian tradition, Borg (1994:121-137) refers to 'macro-stories of scripture'. Stories in the Bible address aspects of the 'human predicament', of which there are three major themes.

The first theme is the story of bondage and liberation, referring to Israel being slaves in Egypt and eventually inheriting the Promised Land. As such, it is 'bondage, liberation, a journey, and a destination' (Borg 1994:122).

The second major theme is about exile and return (Borg 1994:125). Here it is about estrangement and homecoming, or separation from what is known, coupled with powerlessness and marginality, oppression and victimisation.

The third theme is about guilt and forgiveness, as communicated in the priestly tradition (Borg 1994:127).

The everyday experiences and predicaments of ancient Israel were the prompts for a more systematic evaluation and understanding of their situation. The formulation of metaquestions assisted in interpreting contextualised and specific experiences, and, by doing this, put the believers on a road to recovery and healing.

The kind of meta-questions that occupied the minds of people predating our current situation are uncannily similar to what people struggle with today, underscoring the shared human predicament across time and culture. Then, as in today, alienation, powerlessness, oppression, bondage and marginality are central tenets of being human, as can be seen in recent decolonisation debates. The same holds for guilt of the oppressor. The solution of a promised land, however, is still far off.

To use ideas from the realm of religions might seem counterproductive because religion is often seen as divisive and, therefore, not helpful when looking for a common ground between parties in conflict. Even though it is often the case, there is also a common ground to be seen. Barett (Barett \& Keill 1996:243-244; Barrett 2004:6-7), for example, makes a distinction between what he calls 'online' religion (non-reflective beliefs, god concept used in everyday life) and theologically correct religion ('TC'-religion, which is reflective beliefs; see also Barrett 2000, 2007, 2011). Sharing vignettes about god to believers in Bible Belt America, to people in Nepal and India, it seems that people from all religions, when caught unaware that their beliefs are being enquired about, share similar ideas about god, what he or she is, what he or she does and what to expect from him or her. What they share under such circumstances is their online religion, which is almost indistinguishable from any other religion. When specifically questioned to reflect on what they believe in, their TC religion emerged, highlighting stark differences and local beliefs.

This points to the conclusion that similarities exist even in unlikely spheres such as religions and religious traditions, 
which are usually seen as mutually exclusive and having irreconcilable differences. The reason for these underlying similarities arises from the fact that humans share similar neural structures and thinking patterns in their brains, as attested by the neuro-constructivism theory (Dekker \& Karmiloff-Smith 2011:23; Karmiloff-Smith 2006:9-17, 2009a:56; 2009b, 2015:91; Mareschal et al. 2007:91-106; Sirois et al. 2008:321; Westermann et al. 2007). The implication of this is that people from different cultures will be able to communicate if they want to, because there are shared thinking patterns to rely on. It is equally true that brains and thinking are unique. Built upon these shared thinking foundations are distinctive ideas. Novel but constrained ideas are generated constantly, but need to be tested to their relevance, durability and applicability. Once again, relevant learning is mastering the interplay between order and renewal, the accepted and the envisioned.

How is this to be translated into educating humans?

\section{Culturally appropriate education in practice}

Tracy Tokuhama-Espinosa is a prominent figure in the MBES movement (Tokuhama-Espinosa 2010). At the plenary presentation at the 'CALL and the BRAIN 2016' meeting,? entitled 'Neuroconstructivism and the Modern Classroom' (Tokuhama-Espinosa 2017a), she suggested three levels of teaching engagement. It is based on theories of how humans learn $^{8}$ (Tokuhama-Espinosa 2017b) and there she refers to the 1751 description of the tree of human knowledge drawn up by Diderot and d'Alembert (Darnton 1984:194), which is made up of three parts: memory, reason and imagination.

These insights are of crucial importance even today because memory is the storehouse of human intellectual accomplishment and provides the orderly shoulders upon which current innovation stands. Imagination is the capacity to manage and cope with the unforeseen future, which is necessary for growth and also carries the possibility of destructive chaos. Reason is the intermediating capacity to evaluate everything old and new for validity and relevance. What needs to be carried over and kept from the past, preventing us from wasting time and resources by constantly having to re-invent the wheel? What needs to be overhauled or even discarded because it has become irrelevant, outdated and obsolete?

To translate that into teaching practice, Tokuhama-Espinosa (2017a) suggests that we make use of technology for online teaching and that lecturers provide bundles or libraries of material of different levels of complexity to students, which have to be studied by students before they come to a physical or virtual class. The first level is foundational knowledge, terminologies and skills necessary to master and comprehend the theme or issue at hand. It is left to the students themselves 7.See https://www.youtube.com/watch?v=prmLzOKixY8\&t=1375s.

8.See https://www.youtube.com/watch?v=mCrzE5Uj3zU. to decide how much time they need to spend on mastering this level - if they are already well versed in it, they will spend less time, whilst if they are total novices, they might have to spend much time on it. The second level is additional resources and more complex information, and the third level is advanced level sources for higher order learning and thinking about the subject. In this way, it is ensured that all students start on the same page and can communicate about the topic at hand, but they can choose their desired depth of knowledge as is needed in their contexts.

Assessment practices need to support this kind of learning. Assessing the knowledge of non-negotiable foundational concepts, skills and understanding is a necessary starting point. This can be done by means of self-marking assessments, which is feasible in courses with large numbers of students, as is often the case with online courses. Self-marking questions aimed at helping students to evaluate critically the course content, as well as applying it in novel and relevant ways in local contexts, are an indispensable part of assessment, where students need to reflect on and formulate about how to apply the subject content. This reflection is the gateway to meaningful learning, which is the ultimate goal in order to become an online educated human who attained wisdom. In this way, both basic information and knowledge and context-relevant application become feasible (Karpicke 2012:157-163). When basic knowledge is mastered and applied in real-life situations, it leads to a healthy balance between surface, deep and transfer learning (Chin \& Brown 2000; Hattie \& Donoghue 2016).

\section{The future - The ability to learn how to manage change}

Applying material to real-life situations is an excellent way to learn, but it is also true that real-life situations are rapidly changing. Disruption is the order of the day. Several reports have predicted that within 3-12 years, the occupations of almost 800 million people may disappear or change so much that workers will need to be reskilled ranging in time from 6 months to more than 2 years (WEF 2017a, 2017b, 2017c, 2018a, 2018b). Current in-demand occupations and specialties in many industries and countries did not even exist 5 years ago (WEF 2018b), and many occupations that people will occupy in a few years' time do not exist as of yet.

This is also true about education. According to Lemoine, Hackett and Richardson (2017:549), the new educational normal is chaotic, turbulent and rapidly changing. To try to come to terms with this, they refer to a widely used way of trying to make sense of changing times, namely, VUCA an acronym for volatility, uncertainty, complexity and ambiguity - to describe the future (Chai \& Kong 2017:1-3; LeBlanc 2018:23-26).

Volatility refers to unexpected and unstable situations, but which are not too difficult to understand, and which could be prepared for by devoting resources to it. Uncertainty is 
usually the result of something that is known but still out of control. The effects are usually mitigated by investing in more information. Complexity refers to an overwhelming volume of interconnected parts and variables. One person will never be able to manage this, and therefore specialised teams need to be set up. Ambiguity is when we are faced by 'unknown unknowns' and have to traverse completely unknown and unclear terrains with no precedents. The only way to manage this is to experiment, pose and test hypotheses, and learn from mistakes.

There are also other scaffolding structures aimed at managing disruptive change. One of them is Snowden's Cynefin conceptual framework, aimed at supporting decision-making (Kurtz \& Snowden 2003:462; Snowden 1999). According to this framework, decision-making and application of knowledge take place in five domains, namely, the Obvious, the Complicated, the Complex, the Chaotic and Disorder. The Obvious is tightly constrained, and knowledge and application of best practice are needed. In this domain, knowledge of the past and existing expertise is crucial, in the way of 'sense-categorise-respond'. The Complicated is a domain in which we have to manage constraints and where good practice is needed. Here we have to 'sense-analyserespond', once again applying known knowledge in the light of the current constraints. The Complex is a domain where there are no right answers, and we have to 'probe-senserespond' in a safe trial-and-error way leading to emergent practice. The Chaotic is where something totally unexpected happens. Here we have to 'act-sense-respond' and novel practice is needed, afterwards trying to make sense. In the centre is the dark Disorder or Confusion domain, where it is unclear which of the four domains applies.

There are sides and movements related to the four domains. The right side, namely, the Obvious and the Complicated, is characterised by 'order' and known knowledge from the past is necessary to know and to apply. The left side, namely, the Complex and the Chaotic, is characterised by 'chaos', and action is needed to make sense of what is going on. As knowledge is being attained, there is a clockwise drift from the Chaotic and the Complex to the Complicated and the Obvious. A counterclockwise drift is happening when known knowledge is discarded or lost, as, for example, in the call for discarding the so-called 'Western' knowledge from all curricula seen in some quarters of the \#fallist movements.

Volatility, uncertainty, complexity and ambiguity and Cynefin are attempts to make sense of an unknown and changing future in a structured manner. This is similar to what Peterson (1999) describes as the attempt by the son to make sense of the Order and Chaos in the world. It can also be seen in the book of Lamentations, where utter existential and experiential chaos is described in an acrostically ordered way, attempting to come to terms with it (Gous 1996:87, 2005:236).

Attending to past excellence and current relevance is important, as has been argued, but this should happen in a way that imparts future readiness to students. Online education should include ability training, added to mastery of past knowledge and present relevance.

\section{Conclusion}

Is it possible to provide context-relevant education to a diverse body of students via online presented courses? Yes, it is possible, if the past, the present and the future are taken seriously in presenting online courses. We encountered the brain and the mind as sense-making organs, comparable amongst all peoples irrespective of who or where they are, attempting to navigate reality, gathering data and information and turning it into knowledge and wisdom in diverse physical and cultural contexts. Because of this, it is important that presenters of online courses acknowledge the fact that their dispersed students, which may run into hundreds, thousands or even millions, come from a multitude of contexts, and that their present and what they experience as relevant may differ from that of lecturers and other students. Even so, the past and known knowledge need to be taken into account as answers to a shared human condition. All these students and all of their lecturers are on a journey into an unknown future, where their abilities to manage it will mean the difference between surviving and demising.

An online course presented in ways that help students to master the past, to analyse the present and to have the ability to navigate the uncertain future is able to provide context-relevant education and deliver a properly online educated human.

\section{Acknowledgements Competing interests}

The author declares that he has no financial or personal relationships which may have inappropriately influenced him in writing this article.

\section{Author's contributions}

I.G.P.G. is the sole author of this article.

\section{Ethical considerations}

This article followed all ethical standards for a research without direct contact with human or animal subjects.

\section{Funding information}

This research received no specific grant from any funding agency in the public, commercial or not-for-profit sectors.

\section{Data availability statement}

Data sharing is not applicable to this article as no new data were created or analysed in this study.

\section{Disclaimer}

The views and opinions expressed in this article are those of the author and do not necessarily reflect the official policy or position of any affiliated agency of the author. 


\section{References}

Archer, S., 2018, 'The case against free higher education: Why it is neither just no ethical', The Conversation, 27 February, viewed 28 April 2018, from https:// theconversation.com/the-case-against-free-higher-education-why-it-is-neitherjust-nor-ethical-92193.

$\mathrm{Au}, \mathrm{K} ., 2009$, 'Isn't culturally responsive instruction just good teaching?' Socia Education 73(4), 179-183.

Au, K. \& Jordan, C., 1981, 'Teaching reading to Hawaiian children: Finding a culturally appropriate solution', in H. Trueba, B.P. Guthrie \& K.H. Au (eds.), Culture and the bilingual classroom: Studies in classroom ethnography, pp. 139-152, Newbury bilingual classroom: Studies in
House Publishers, Rowley, MA.

Barrett, J.L., 2000, 'Exploring the natural foundations of religion', Trends in Cognitive Sciences 4(1), 29-34. https://doi.org/10.1016/S1364-6613(99)01419-9

Barrett, J.L., 2004, Why would anyone believe in God?, AltaMira, Walnut Creek, CA.

Barrett, J.L., 2007, 'Cognitive science of religion: What is it and why is it?', Religion Compass 1(6), 768-786. https://doi.org/10.1111/j.1749-8171.2007.00042.x

Barrett, J.L., 2011, 'Cognitive science of religion: Looking back, looking forward', Journal for the Scientific Study of Religion 50(2), 229-239. https://doi org/10.1111/j.1468-5906.2011.01564.x

Barrett, J.L. \& Keil, F.C., 1996, 'Conceptualizing a nonnatural entity: Anthropomorphism in God concepts', Cognitive Psychology 31(3), 219-247. https://doi.org/10.1006/ cogp.1996.0017

Baumgartner, L.M. \& Johnson-Bailey, J., 2008, 'Fostering awareness of diversity and multiculturism in adult and higher education', New Directions for Continuing Education 2008(120), 45-53. https://doi.org/10.1002/ace.315

Biggs, J.B. \& Tang, C., 2011, Teaching for quality learning at university: What the student does, McGraw-Hill Education, Berkshire.

Borg, M.J., 1994, Meeting Jesus again for the first time: The historical Jesus and the heart of contemporary faith, Harper Collins, New York, NY.

Braddick, O., Atkinson, J. \& Innocenti, G.M. (eds.), 2011, Gene Expression to Neurobiology and Behaviour: Human Brain Development and Developmental Disorders (Progress in brain research, vol. 189), pp. 23-33, Elsevier, Amsterdam. Disorders (Progress in brain research, vol. 189 )
ISBN: 978-0-444-53884-0, ISSN: 0079-6123.

Brown, P.C., Roediger, H.L. \& McDaniel, M.A., 2014, Make it stick: The science of successful learning, Harvard University Press, Cambridge, MA.

Brown-Jeffy, S. \& Cooper, J.E., 2011, 'Toward a conceptual framework of culturally relevant pedagogy: An overview of the conceptual and theoretical literature', Teacher Education Quarterly 38(1), 65-84.

Caine, G. \& Caine, R.N., 2006, 'Meaningful learning and the executive functions of the brain', New Directions for Adult and Continuing Education 2006(110), 53-61. https://doi.org/10.1002/ace.219

Carew, T.J. \& Magsamen, S.H., 2010, 'Neuroscience and education: An ideal partnership for producing evidence-based solutions to guide 21st century learning', Neuron 67(5), 685-688. https://doi.org/10.1016/j.neuron.2010.08.028

Cazden, C.B. \& Leggett, E.L., 1981, 'Culturally responsive education: Recommendations for achieving Lau remedies', in H.T. Trueba, G.P. Guthrie \& K.H. Au (eds.), Culture and the bilingual classroom: Studies in classroom Ethnography, pp. 69-86, Newbury House Publishers, Rowley, MA.

Chai, C.S. \& Kong, S.C., 2017, 'Professional learning for 21st century education', Journal of Computers in Education 4(1), 1-4.

Chaudhuri, A., 2016, 'The real meaning of RhodesMustFall', The Guardian, 16 March, viewed 28 April 2018, from https://www.theguardian.com/uk-news/2016/ mar/16/the-real-meaning-of-rhodes-must-fall.

Chin, C. \& Brown, D.E., 2000, 'Learning in science: A comparison of deep and surface approaches', Journal of Research in Science Teaching: The Official Journal of the National Association for Research in Science Teaching 37(2), 109-138. https://doi org/10.1002/(sici)1098-2736(200002)37:2<109::aid-tea3>3.0.co;2-7

Costandius, E., Blackie, M., Nell, I., Malgas, R., Alexander, N., Setati, E. et al., 2018, '\#FeesMustFall and decolonising the curriculum: Stellenbosch University students' and lecturers' reactions', South African Journal of Higher Education 32(2), 65-85.

Cozolino, L. \& Sprokay, S., 2006, 'Neuroscience and adult learning', New Directions for Adult and Continuing Education 2006(110), 11-19. https://doi.org/10.1002/ ace. 214

Darnton, R., 1984, 'Philosophers trim the tree of knowledge: The epistemological strategy of the Encyclopédie', in The great cat massacre and other episodes in French cultural history, pp. 191-215, Basic Books, New York, NY.

Dekker, T.M. \& Karmiloff-Smith, A., 2011, 'The dynamics of ontogeny: A neuroconstructivist perspective on genes, brains, cognition and behaviour', in $\mathrm{O}$. Braddick, J. Atkinson \& G.M. Innocenti (eds.), Gene Expression to Neurobiology and Behaviour: Human Brain Development and Developmental Disorders (Progress in brain research, vol. 189), pp. 23-33, Elsevier, Amsterdam.

Doyle, T. \& Zakrajsek, T., 2013, The new science of learning. How to learn in harmony with your brain, Stylus Publishing, Stirling, VA.

Dube, B., 2017, 'Afrikaans must fall and English must rise - Ironies and contradictions in protests by South African university students', Africa Insight 47(2), 13-27.

Dunlosky, J., Rawson, K.A., Marsh, E.J., Nathan, M.J. \& Willingham, D.T., 2013 'Improving students' learning with effective learning techniques: Promising directions from cognitive and educational psychology', Psychological Science in the Public Interest 14(1), 4-58. https://doi.org/10.1177/1529100612453266
Dyer, W.W., 2009, The shift: Taking your life from ambition to meaning, Hay House, Carlsbad, CA.

Earley, P.C. \& Ang, S., 2003, Cultural intelligence: An analysis of individual interactions across cultures, Stanford University Press, Palo Alto, CA.

Entwistle, N. \& Ramsden, P., 2015, Understanding student learning (Routledge revivals), Routledge, New York, NY.

Erickson, F. \& Mohatt, G., 1982, 'Cultural organization of participation structures in two classrooms of Indian students', in G. Spindler (ed.), Doing the ethnography of schooling: Educational anthropology in action, pp. 132-174, Holt, New York, NY.

Fomunyam, K., 2017, 'Curriculum responsiveness within the context of decolonisation in South African higher education', Perspectives in Education 35(2), 196-207. https://doi.org/10.18820/2519593X/pie.v35i2.15

Gous, I.G.P., 1996, 'Mind over matter: Lamentations 4 in the light of the cognitive sciences', Scandinavian Journal of the Old Testament 10(1), 69-87. https://doi. org/10.1080/09018329608585083

Gous, I.G.P., 2005, 'Lamentations 4 in the light of poetry therapy', Old Testament Essays 18(2), 223-239.

Gous, I.G.P., 2007, 'Meaning - Intelligently designed. Keeping the Bible in a (modern) mind', Old Testament Essays 20 (1), 34-52.

Henry, N.L., 1974, 'Knowledge management: A new concern for public administration', Public Administration Review 34(3), 189-196. https://doi.org/10.2307/974902

Hattie, J.A. \& Donoghue, G.M., 2016, 'Learning strategies: A synthesis and conceptual model', npj Science of Learning 1, 16013. https://doi.org/10.1038/ npjscilearn.2016.13

Heleta, S., 2016, 'Decolonisation of higher education: Dismantling epistemic violence and Eurocentrism in South Africa', Transformation in Higher Education 1(1), a9. http://doi.org/10.4102/the.v1i1.9

Jordan, C., 1985, 'Translating culture: From ethnographic information to educational program', Anthropology \& Education Quarterly 16(2), 105-123. https://doi. org/10.1525/aeq.1985.16.2.04x0631g

Kahneman, D., 2011, Thinking, fast and slow, Farrar, New York, NY.

Karmiloff-Smith, A., 2006, 'The tortuous route from genes to behavior: A neuroconstructivist approach', Cognitive, Affective, and Behavioral Neuroscience neuroconstructivist approach', Cognitive, Affective,
6(1), 9-17. https://doi.org/10.3758/CABN.6.1.9

Karmiloff-Smith, A., 2009a, 'Nativism versus neuroconstructivism: Rethinking the study of developmental disorders', Developmental Psychology 45(1), 56-63. https://doi.org/10.1037/a0014506

Karmiloff-Smith, A., 2009b, 'Preaching to the converted? From constructivism to neuroconstructivism', Child Development Perspectives 3(2), 99-102. https://doi. org/10.1111/j.1750-8606.2009.00086.x

Karmiloff-Smith, A., 2015, 'An alternative to domain-general or domain-specific frameworks for theorizing about human evolution and ontogenesis', AIMS Neuroscience 2(2), 91. https://doi.org/10.3934/Neuroscience.2015.2.91

Karpicke, J.D., 2012, 'Retrieval-based learning: Active retrieval promotes meaningful learning', Current Directions in Psychological Science 21(3), 157-163. http://doi. org/10.1177/0963721412443552

Kurtz, C.F. \& Snowden, D.J., 2003, 'The new dynamics of strategy: Sense-making in a complex and complicated world', IBM Systems Journal 42(3), 462-483. https:// doi.org/10.1147/sj.423.0462

Ladson-Billings, G., 1995, 'Toward a theory of culturally relevant pedagogy', American Educational Research Journal 32(3), 465-491. https://doi. org/10.3102/00028312032003465

Laurillard, D., 2002, Rethinking university teaching: A conversational framework for the effective use of learning technologies, Routledge, London.

Lebeloane, L., 2017, 'Decolonizing the school curriculum for equity and social justice in South Africa', KOERS - Bulletin for Christian Scholarship 82(3), 1-10. https://doi. in South Africa', KOERS - Bulletin
org/10.19108/KOERS.82.3.2333

LeBlanc, P.J., 2018, 'Higher education in a VUCA world', Change: The Magazine of Higher Learning 50(3-4), 23-26. https://doi.org/10.1080/00091383.2018.150 Higher
7370

Lee, C.D., 1998, 'Culturally responsive pedagogy and performance-based assessment', Journal of Negro Education 67(3), 268-279. https://doi.org/10.2307/2668195

Le Grange, L., 2018, 'Decolonising the university curriculum', South African Journal of Higher Education 30(2), 2-12. https://doi.org/10.20853/30-2-709

Lemoine, P.A., Thomas Hackett, P. \& Richardson, M.D., 2017, 'Global higher education and VUCA - Volatility, uncertainty, complexity, ambiguity', in S. Mukerji \& P. Tripathi (eds.), Handbook of research on administration, policy, and leadership in higher education, pp. 549-568, IGI Global, Hershey, PA.

Mamdani, M., 2019, 'Decolonising universities', in J.D. Jansen (ed.), Decolonisation in universities: The politics of knowledge, Wits University Press, Johannesburg.

Mareschal, D., Johnson, M.H., Sirois, S., Thomas, M.S., Spratling, M. \& Westermann, G., 2007, Neuroconstructivism: How the brain constructs cognition, vol. 1, Oxford University Press, Oxford.

Mohatt, G. \& Erickson, F., 1981, 'Cultural differences in teaching styles in an Odawa school: A sociolinguistic approach', in H.T. Trueba, G.P. Guthrie \& K.H. Au (eds.), Culture and the bilingual classroom: Studies in classroom ethnography, pp. 105-119, Newbury House Publishers, Rowley, MA.

Musitha, M.E. \& Mafukata, M.A., 2018, 'Crisis of decolonising education: Curriculum implementation in Limpopo Province of South Africa', Africa's Public Service Delivery and Performance Review 6(1), 179. https://doi.org/10.4102/apsdpr. V6i1.179 
Ndlovu-Gatsheni, S.J., 2013, 'Decolonising the university in Africa', The Thinker 51, 46-51.

Nyamnjoh, A., 2017, 'The phenomenology of Rhodes Must Fall: Student activism and the experience of alienation at the University of Cape Town', Strategic Review for Southern Africa 39(1), 256-277.

Peck, M.S., 1978, The road less travelled: A new psychology of love, traditional values and spiritual growth, Simon and Schuster, New York, NY.

Peterson, J.B., 1999, Maps of meaning: The architecture of belief, Routledge New York, NY

Pretorius, S.G., 2014, 'Educators' perceptions of school effectiveness and dysfunctional schools in South Africa', Journal of Social Sciences 40(1), 51-64. https://doi.org/ 10.1080/09718923.2014.11893302

Reyhner, J., Gilbert, W.S. \& Lockard, L. (eds.), 2010, Honoring our heritage: Culturally appropriate approaches for teaching indigenous students, Northern Arizona University Press, Flagstaff, AZ.

Rowley, J., 2007, 'The wisdom hierarchy: Representations of the DIKW hierarchy', Journal of Information Science 33(2), 163-180. https://doi. org/10.1177/0165551506070706

Sayed, Y., Motala, S. \& Hoffman, N., 2018, 'Decolonising initial teacher education in South African universities: More than an event', Journal of Education 68, 59-92.

Sirois, S., Spratling, M., Thomas, M.S., Westermann, G., Mareschal, D. \& Johnson, M.H., 2008, 'Précis of Neuroconstructivism: How the brain constructs cognition' Behavioral and Brain Sciences 31(3), 321-331. https://doi.org/10.1017/ S0140525X0800407X

Snowden, D., 1999, 'Liberating knowledge', in Liberating knowledge, CBI Business Guide, pp. 9-19, Caspian Press, London.

Taylor, J.C., 2001, 'Fifth generation distance education', Instructional Science and Technology 4(1), 1-14.

Tokuhama-Espinosa, T., 2010, Mind, brain, and education science: A comprehensive guide to the new brain-based teaching, W.W. Norton \& Company, New York, NY.

Tokuhama-Espinosa, T., 2017a, Neuroconstructivism and the modern classroom, viewed 07 May 2018, from https://www.youtube.com/watch?v=prmLz0KixY8\&t=1375s.

Tokuhama-Espinosa, T., 2017b, Theories of how humans learn, viewed 07 May 2018, from https://www.youtube.com/watch?v=mCrzE5Uj3zU.
Viewed from https://ewn.co.za/Topic/Fees-must-fall.

Viewed from https://onlinelibrary.wiley.com/journal/1751228x.

Viewed from https://www.isls.org/communities/journal-of-the-learning-sciences.

Viewed from https://www.sahistory.org.za/dated-event/chumani-maxwele-ignitesrhodesmustfall-movement-uct.

Viewed from https://mg.co.za/article/2016-03-10-whiteness-not-afrikaans-mustfall.

Viewed from https://www.iol.co.za/news/south-africa/gauteng/why-were-bringingafrikaansmustfall-back-2026394.

Vogt, L.A., Jordan, C. \& Tharp, R.G., 1987, 'Explaining school failure, producing school success: Two cases', Anthropology \& Education Quarterly 18(4), 276-286. http:// doi.org/10.1525/aeq.1987.18.4.04x0019s

Wallace, D.P., 2007, Knowledge management: Historical and cross-disciplinary themes, Libraries Unlimited, Westport, CT.

WEF, 2017a, The future of jobs and skills in Africa - Preparing the region for the fourth industrial revolution, White Paper, World Economic Forum, Geneva.

WEF, 2017b, Realizing human potential in the fourth industrial revolution: An agenda for leaders to shape the future of education, gender and work, White Paper, World Economic Forum, Geneva.

WEF, 2017c, Deloitte global human capital trends: Rewriting the rules for the digital age, White Paper, World Economic Forum, Geneva.

WEF, 2018a, Eight futures of work: Scenarios and their implications, White Paper, World Economic Forum, Geneva.

WEF, 2018b, The future of jobs, White Paper, World Economic Forum, Geneva.

Westermann, G., Mareschal, D., Johnson, M.H., Sirois, S., Spratling, M.W. \& Thomas, M.S., 2007, 'Neuroconstructivism', Developmental Science 10(1), 75-83.

Zeleny, M., 2005, Human systems management: Integrating knowledge, management and systems, World Scientific Publishing Co. (Pty) Ltd., Singapore.

Zhou, J. \& Fischer, K.W., 2013, 'Culturally appropriate education: Insights from educational neuroscience', Mind, Brain, and Education 7(4), 225-231. https://doi. org $/ 10.1111 / \mathrm{mbe} .12030$ 